\title{
Grand corruption scandals in the Philippines
}

\author{
Eric V.C. Batalla
}

De la Salle University, Manila, Philippines

\begin{abstract}
Purpose - The purpose of this article is to analyse the weaknesses of governance institutions in constraining grand corruption arising from the government procurement of large foreign-funded infrastructure projects in the Philippines. The weaknesses are revealed in the description and analysis of two major scandals, namely, the construction of the Bataan Nuclear Power Plant during the Marcos era and the National Broadband Network project of the Arroyo presidency.

Design/methodology/approach - This research employs a historical and comparative case approach to explore patterns of grand corruption and their resolution. Primary and secondary data sources including court decisions, congressional records, journal articles and newspaper reports are used to construct the narratives for each case.

Findings - Top-level executive agreements that do not require competitive public bidding provide an opportunity for grand corruption. Such agreements encourage the formation of corrupt rent-seeking relationships involving the selling firm, brokers, politicians and top-level government executives. Closure of cases of grand corruption is a serious problem that involves an incoherent and politically vulnerable prosecutorial and justice system.

Originality/value - This paper aims to contribute to research on grand corruption involving the executive branch in the Philippines, particularly in the procurement of large, foreign-funded government projects. It examines allegations of improprieties in government project contracting and the politics of resolving corruption scandals through the justice system.
\end{abstract}

Keywords Grand corruption scandals, Bataan Nuclear Power Plant, NBN-ZTE scandal, infrastructure projects, Philippines

Paper type Research paper

\section{Introduction}

Grand corruption scandals are a regular occurrence in the Philippines, tainting many presidential administrations (Mathews and Wideman, 1977; Mydans, 1988; Coronel and Tordesillas, 1998; Rimando, 2000; Hutchcroft, 2008). Grand corruption refers to the "abuse of high level power that benefits the few at the expense of the many" (Transparency International, 2016). Corruption at this level usually involves large sums of financial and state resources.

Popular thinking in recent years has attributed grand corruption simply to regime types (authoritarian vs democratic). This thinking is flawed. Corruption at various levels of government is rampant in weak or inferior democracies than in well-developed ones, leading to the belief that having a democracy alone does not guarantee effective control of corruption (UNODC, 2019; Kukutschka, 2018). Similarly, the level of corruption varies across authoritarian systems, with monarchies and single-party systems tending to be less corrupt than military and personalistic regimes; in fact, as Kukutschka (2018, p. 4) points out, "a small number of non-democratic countries perform relatively well in international corruption indices." In either democratic or authoritarian systems, the commission of grand

(C) Eric V.C. Batalla. Published in Public Administration and Policy. Published by Emerald Publishing Limited. This article is published under the Creative Commons Attribution (CC BY 4.0) license. Anyone may reproduce, distribute, translate and create derivative works of this article (for both commercial and non-commercial purposes), subject to full attribution to the original publication and authors. The full terms of this license may be seen at http://creativecommons.org/licences/by/4.0/legalcode

The author thanks Professor Jon Quah for his editorial initiative and support for this work. Thanks are also due to Emil Bolongaita and Cleo Calimbahin for their useful comments and suggestions.

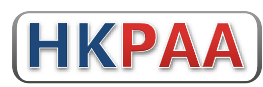

Received 11 November 2019

Revised 9 January 2020 Accepted 28 February 2020

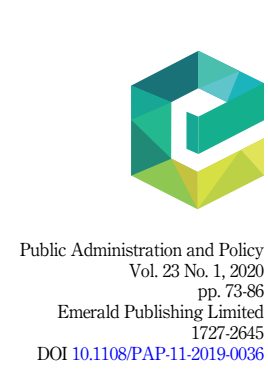


PAP

23,1

corruption is typically driven by personalistic and patronage-clientelistic motivations that benefit rulers and the dominant political elite, political parties and allies, cronies and friends, as well as families and relatives (David-Barrett and Fazekas, 2019; Chang and Golden, 2010).

In the Philippines, grand corruption knows no political regime; its occurrence has been observed in both authoritarian and democratic governments. Thus, instead of simply regime type, it could be argued that it is the continued weakness of governance institutions that allows the culture and agency of corruption to thrive and persist, even at the highest levels of government. Despite the proliferation of anti-corruption laws, a perennially weak accountability environment and the ineffectiveness of the country's anti-corruption agencies encourage strategic rent-seeking by private firms and individuals through deception and bribes (or income transfer) to government officials. Furthermore, an inefficient prosecutorial and judicial system, often subservient to political power, encourages corruption by failing to punish crimes of powerful individuals and firms. All this constitutes the collective inability of institutional and agency constraints to overpower the forces that create, adapt and maintain the opportunities for corruption.

The scandals that affect many Philippine presidential administrations reflect this inability of both state and society to curb opportunities for grand corruption. Scandal, according to Lowi (1988, p. vii) is "corruption revealed;" it is "breach of virtue exposed." In his analysis of scandals, Lowi (1988, p. viii) argues that the exposé of corruption (the first news break or the substantive scandal) is often followed by a more controversial cover-up phase or the procedural scandal. The cover-up extends the scandal's media coverage and further erodes a political administration's integrity and legitimacy. Hence, the unpacking of a corruption scandal could be guided by an examination of its substantive and procedural stages. The analysis should also cover the scandal's resolution or closure.

Following the theme of this special issue of Public Administration and Policy, this article examines and compares two corruption scandals involving large infrastructure projects of government, namely, the Bataan Nuclear Power Plant (BNPP) of the Marcos era and the National Broadband Network (NBN) project of the Arroyo presidency. These two projects are amongst the most controversial political corruption scandals during the last 50 years. Their comparison enhances the understanding of grand corruption in government-initiated projects involving foreign government and corporate entities. To construct the narratives of each case, primary and secondary sources are utilized, including court decisions, laws published in the Official Gazette, Senate committee reports, journal articles, biographies and newspaper reports. The following sections provide descriptive accounts of the BNPP and NBN scandals, followed by the comparative analysis and conclusion.

\section{The BNPP scandal}

In July 1973, based on a feasibility study conducted by the International Atomic Energy Association (IAEA), President Ferdinand Marcos announced his decision to build the country's first nuclear power plant in the Bataan province. Soon after the announcement, the National Power Corporation (NPC), as the main implementing agency, began the work of undertaking the necessary technical studies as well as negotiate with vendor and financing institutions.

General Electric (GE) was the first to respond and worked with NPC for months to secure the contract. On 14 June 1974, GE presented a 200-page prospectus to the NPC and Presidential Executive Secretary Alejandro Melchor, Jr. who also served as the NPC director. Accordingly, on that very day, the NPC formally approved the Westinghouse offer (Dumaine, 1986). The NPC approval was in accordance with Marcos' decision during a cabinet meeting on 6 June to give the contract to Westinghouse (PCGG vs Desierto et al., 2003).

Westinghouse out-manoevered GE by employing Herminio Disini as its special sales representative. Disini was a golfing buddy of the president and was married to Imelda Marcos' cousin and family physician. Through his close presidential connection, Disini was 
able to build a vast business empire in a short span of time after the imposition of martial rule. His Herdis Management and Investment Corporation (Herdis), which was established in 1969 with a bank loan of only US $\$ 3,500$, was ranked 15th amongst the country's top 1,000 corporations in 1976, with consolidated assets amounting to US\$140 million (Manapat, 1991, p. 316). At the time of its divestment in 1981, the Herdis group included more than 30 companies under its umbrella.

In April 1974, Westinghouse sent a turn-key proposal to Marcos. A month later, a company delegation went to the Philippines to brief the president on the proposal to supply two 620-MW pressured water reactors for a reported cost of US\$500 million. NPC general manager Ramon Ravanzo claimed that during the meeting Westinghouse only provided standard advertising brochures without any detailed costs and specifications (Butterfield, 1978).

Immediately following Marcos's approval, Melchor signed a letter of commitment giving approval for Westinghouse and NPC to firm up the project contract. However, contract negotiations dragged on for more than a year. One of the issues raised by NPC was that many contract provisions were "onerous, unacceptable, or inconsistent with the turn-key approach to project implementation” (PCGG vs Desierto et al., 2003).

In November 1975, the final negotiated contract was transmitted to Solicitor General Estelito Mendoza for review. Mendoza recommended the rejection of the contract because of those provisions deemed onerous and disadvantageous to the government. Notwithstanding Mendoza's objections, Marcos ordered the NPC to sign the contract with Westinghouse (PCCG vs Desierto et al., 2003). In February 1976, close to two years after the approval of the Westinghouse proposal, the two parties formally signed the final contract. The U.S. government, through its Export-Import Bank, provided project financing with a US\$272.2 million loan and a guarantee of an additional US $\$ 367.2$ million for NPC bonds.

The final contract revealed three significant changes from the original 1974 proposal. First, the total project cost reached US $\$ 1.1$ billion for one reactor compared to the original estimate of US\$500 million for two reactors. Of the revised total project cost, Westinghouse would share US $\$ 677.1$ million (or $61 \%$ of total cost) and NPC US $\$ 432.3$ million.

Second, the parties agreed to transfer the site from Bagac, which was found to be more vulnerable to tidal waves, to Morong, which was 18 metres above sea-level but nearer a volcano. The site transfer led the parties to design a facility that could withstand an earthquake with a magnitude of 7.9 on the Richter scale. Safety considerations for the site transfer raised the cost of the original contract.

Lastly, the contract changed the scope of work for Westinghouse. Initially, it was understood that Westinghouse would only provide design engineering and project construction management services. However, in January 1975, on the basis of an Aide Memoire from Westinghouse, Marcos ordered the NPC to leave the business of construction to Westinghouse "since the concept is totally turnkey" (Republic of the Philippines vs. Herminio T. Disini et al., 2012, p. 37).

\section{Commissions and other income}

It is not clear how much commissions Disini and by extension, Marcos received from Westinghouse. Subsequent reports citing bankers and former Disini associates indicated varying amounts, ranging from a few million dollars to more than US\$50 million. Initially refusing to disclose information for proprietary reasons, Westinghouse eventually revealed that Disini received commissions of at least US $\$ 18$ million for the period 1976-1982 (Beaver, 1994; PCGG vs Desierto et al., 2003). As sums were paid to him, no bribery of top-level Philippine government officials (including Marcos) was proven, which might have otherwise made Westinghouse legally liable under the U.S. Foreign Corrupt Practices Act of 1977.

Disini's profit from the BNPP project was not limited to commissions. His companies also engaged in underwriting insurance, construction, distribution of Westinghouse products and 
PAP

23,1

services as well as the setting up of communications for the power plant project (Matthews and Wideman, 1977). Further, Disini intervened to make Citicorp the lead manager of the syndicated loan partly financing the BNPP despite a presidential decree that originally gave the role to American Express Bank (Butterfield, 1978). The presidential committee on the BNPP formed in January 1988 by President Corazon Aquino alleged that Disini and Westinghouse influenced Marcos to displace the American Express Bank in November 1974 in favour of Citicorp (Tiglao, 1992).

\section{Media exposé and response}

More than a year after the contract signing, a series of reports from the Washington Post followed by the New York Times, criticized Disini's Marcos connection as well as his involvement in the BNPP. In an interview with the Washington Post in December 1977, Marcos reportedly said that the decision to buy the Westinghouse plant was made based on a report by foreign technical consultants and that was before Disini's involvement with Westinghouse.

That explanation did not stop U.S. media criticisms of corruption and rising crony capitalism, as represented by the BNPP, as well as the spectacular rise of the Disini business empire through presidential influence. In response, Marcos ordered the Ministry of Energy and Ministry of Justice to investigate Disini's involvement in the award to Westinghouse (Butterfield, 1978). He also directed the government takeover of three Disini firms, in which the government had substantial financial exposure. Then Press Secretary Francisco Tatad explained that the takeovers were done not because of any wrongdoing by Disini but because the government had large investments in the three companies (Mathews and Wideman, 1978).

In 1981, in the midst of an international recession and piling debt, many crony empires, including Herdis, collapsed. This led Marcos to order the government bailout and takeover of 13 major Herdis companies and transferred them to the government-owned National Development Company (Branigin, 1984). In 1982, Disini fled to Austria, a country without an extradition treaty with the Philippines. There, he allegedly acquired citizenship and a castle. He passed away in 2014 (ABS-CBN News, 2014).

\section{Increased project costs}

While plant construction was undergoing in March 1979, a nuclear disaster struck in the United States at Three Mile Island (TMI). The TMI accident caused a partial nuclear meltdown, therefore raising alarm worldwide about the safety of nuclear energy. Consequently, the U.S. Nuclear Regulatory Commission (USNRC) issued guidelines for the upgrading of plant design and equipment requirements as well as other disaster preventive measures (USNRC, 2018, pp. 2-3).

In response, Marcos in June 1979 ordered a stop to BNPP construction activities. By virtue of Executive Order No. 539, he established a presidential commission to enquire into the safety of the BNPP. The commission, otherwise known as the Puno Commission because it was headed by then Justice Minister Ricardo Puno, submitted its report in November 1979, recommending the continuation of plant construction subject to the incorporation of additional safety features in the revised design (Republic of the Philippines, 1980, p. 1).

For its part, in August 1980, the Philippine Atomic Energy Commission (PAEC), the country's nuclear regulatory body, submitted its own re-evaluation study, which recommended the lifting of the construction suspension order. The PAEC further required the NPC to address 33 regulatory guides, nine TMI-related requirements and two IAEA concerns (Republic of the Philippines, 1980, p. 2). Based on the recommendations of the Puno Commission and PAEC, Marcos directed the NPC to resume construction of the BNPP.

These developments arising from the TMI accident ultimately resulted in a sharp spike in project cost mainly due to interest charges, inflation, foreign exchange losses and costs of 
additional safety requirements. According to former Energy Minister Geronimo Velasco, the incremental costs shouldered by the NPC following the recommendations amounted to US\$844 million, which included safety upgrades (US\$100 million), cost escalation (US\$292 million), financing charges (US\$373 million) and other contract scope changes (US\$79 million). Consequently, by 1984, the revised BNPP project cost estimate reached US $\$ 1.95$ billion (Velasco, 2006, p. 111).

The BNPP was completed in mid-1985 and was prepared to operate in December. However, political considerations led Marcos to postpone operations until after the 1986 snap elections. By early 1986, the total project cost had risen to US $\$ 2.1$ billion, or a billion dollars more than the original contract price in 1976. It took more than 20 years before the Philippines could fully settle the NPC's BNPP financial obligations. Based on the Bureau of Treasury's statistics on debt service for the period 1986-2007, Table 1 shows that the country paid a total sum of PhP62.4 billion for the nuclear power plant (or about US\$3 billion based on the February 1986 average exchange rate of PhP20.46 per US dollar). Of the total amount of payment, $\mathrm{PhP} 18.88$ billion were for interest (which ended in 2003) and $\mathrm{PhP} 43.56$ billion were for principal amortization (which ended in 2007).

\section{Recovery of ill-gotten wealth}

Days after Marcos' ouster in February 1986, Corazon Aquino issued Executive Order No. 1, creating the Presidential Commission on Good Government (PCGG) to recover the ill-gotten wealth of the Marcos family and associates. The PCGG found plausible documentary

\begin{tabular}{|c|c|c|c|c|c|c|c|}
\hline \multirow[b]{2}{*}{ Year } & \multicolumn{3}{|c|}{ Interest payments } & \multicolumn{3}{|c|}{ Principal amortization } & \multirow[b]{2}{*}{$\begin{array}{c}\text { Total interest and } \\
\text { amortization }\end{array}$} \\
\hline & Domestic & Foreign & $\begin{array}{c}\text { Total } \\
\text { interest }\end{array}$ & Domestic & Foreign & $\begin{array}{c}\text { Total } \\
\text { amortization }\end{array}$ & \\
\hline 1986 & 1,177 & 0 & 1,177 & 0 & 0 & 0 & 1,177 \\
\hline 1987 & 597 & 1,706 & 2,303 & 1,605 & 882 & 2,487 & 4,790 \\
\hline 1988 & 337 & 1,700 & 2,037 & 1,524 & 1,759 & 3,283 & 5,320 \\
\hline 1989 & 165 & 1,507 & 1,672 & 1,488 & 1,962 & 3,450 & 5,122 \\
\hline 1990 & 80 & 1,915 & 1,995 & 0 & 2,452 & 2,452 & 4,447 \\
\hline 1991 & 57 & 1,682 & 1,739 & 0 & 2,789 & 2,789 & 4,528 \\
\hline 1992 & 37 & 1,096 & 1,133 & 0 & 270 & 270 & 1,403 \\
\hline 1993 & 20 & 1,386 & 1,406 & 0 & 5,189 & 5,189 & 6,595 \\
\hline 1994 & 39 & 842 & 881 & 0 & 2,725 & 2,725 & 3,606 \\
\hline 1995 & 22 & 1,113 & 1,135 & 92 & 934 & 1,026 & 2,161 \\
\hline 1996 & 36 & 1,107 & 1,143 & 64 & 935 & 999 & 2,142 \\
\hline 1997 & 56 & 792 & 848 & 112 & 2,273 & 2,385 & 3,233 \\
\hline 1998 & 40 & 667 & 707 & 99 & 841 & 940 & 1,647 \\
\hline 1999 & 30 & 608 & 638 & 95 & 1,573 & 1,668 & 2,306 \\
\hline 2000 & 32 & 0 & 32 & 113 & 1,599 & 1,712 & 1,744 \\
\hline 2001 & 24 & 0 & 24 & 125 & 1,654 & 1,779 & 1,803 \\
\hline 2002 & 7 & 0 & 7 & 125 & 1,637 & 1,762 & 1,769 \\
\hline 2003 & 3 & 0 & 3 & 132 & 1,748 & 1,880 & 1,883 \\
\hline 2004 & 0 & 0 & 0 & 0 & 1,988 & 1,988 & 1,988 \\
\hline 2005 & 0 & 0 & 0 & 0 & 1,970 & 1,970 & 1,970 \\
\hline 2006 & 0 & 0 & 0 & 0 & 1,761 & 1,761 & 1,761 \\
\hline 2007 & 0 & 0 & 0 & 0 & 1,045 & 1,045 & 1,045 \\
\hline Total & 2,759 & 16,121 & 18,880 & 5,574 & 37,986 & 43,560 & 62,440 \\
\hline
\end{tabular}

Note(s): Data on government payments for the BNPP prior to 1986 not available

Source(s): The author's calculations are based on the online statistics on national government debt service provided in the Bureau of the Treasury (2020)

Grand corruption scandals

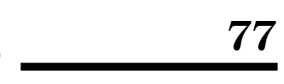


PAP

23,1

evidence left behind by Marcos in connection with the BNPP project. In July 1987, it filed a civil complaint against Disini, Ferdinand and Imelda Marcos, and former Herdis group president, Rodolfo Jacob. The complaint, known as Civil Case No. 13, alleged that the codefendants colluded unlawfully to acquire and accumulate ill-gotten wealth (Republic of the Philippines vs. Disini et al., 2012).

Later that year, the Aquino government sued Westinghouse and its engineering subcontractor, Burns and Roe, for bribery, fraud and racketeering before a federal district court in New Jersey (Butterfield, 1988). The government demanded US\$6.6 billion in compensation from the two firms. Westinghouse, however, convinced the court that the case should stay pending arbitration by the International Chamber of Commerce in Switzerland, as provided in the BNPP contract (Republic of the Philippines vs. Westinghouse Electric Corporation, 1989).

In 1991, the Swiss arbitration panel cleared Westinghouse of bribery charges (United Press International, 1991). In May 1993, the federal court jury in New Jersey also reached a verdict exonerating the two American companies. In 1995, while cases in Switzerland and in a U.S. appellate court were ongoing, the Ramos government decided for a US $\$ 100$ million outof-court settlement with Westinghouse. Based on that agreement, the Philippine government would receive US $\$ 40$ million in cash and two combustion engines worth US $\$ 30$ million each. By virtue of this out-of-court settlement, all other pending cases against Westinghouse on the BNPP project were dropped (Asian Wall Street Journal, 1995).

In contrast, the civil suit against Disini dragged on for a longer time. Legal tactics and jurisdictional conflict among the PCGG and Office of the Ombudsman (OMB) delayed settlement by the Sandiganbayan, the country's anti-graft court. It took 25 years before the court could resolve Civil Case No. 13 (Republic of the Philippines vs. Disini et al., 2012; PCGG vs Desierto et al., 2003).

During the early course of its investigation, the PCGG successfully convinced former Herdis executives to be whistle-blowers. These included former Herdis president Rodolfo Jacob, former Asia Industries president Jesus Vergara, former vice president Angelo Manahan and former legal vice president and cousin, Jesus Disini. Jacob had claimed that Disini's commissions were deposited in his personal Swiss bank accounts and not to Herdis' accounts. Disini's cousin, Jesus, also testified that Marcos owned two-thirds of Herdis (ABS-CBN News, 2009).

Surprisingly in 1997, the OMB then headed by Ananiano Desierto cleared Disini of graft charges for lack of prima facie evidence (PCGG vs Desierto et al., 2003). The PCGG appealed the OMB's decision before the Supreme Court. Six years later, the Supreme Court reversed the $1997 \mathrm{OMB}$ order and directed the OMB to file in the appropriate court the appropriate criminal charges. Thus, in 2004, then Ombudsman Simeon Marcelo filed two criminal cases against Disini, one for bribery and the other for violation of Section 4(a) of the Anti-Graft and Corrupt Practices Act, which prohibits a private individual from exploiting close personal ties with a public official in order to gain some pecuniary or material advantage. Consequently, Disini was arrested but was later released on PhP54,000 bail.

In 2012, the Sandiganbayan ruled against Disini, ordering the return to the government his commissions, deemed as ill-gotten wealth, amounting to US\$50,562,500 (Republic of the Philippines vs Disini et al., pp. 50-51; Salaverria, 2012). However, despite establishing the fact that Marcos and Disini were close associates (and relatives by affinity) and that Marcos acted in favour of Disini as Westinghouse's special agent, the court could not find preponderant evidence that the Marcoses received any commissions from the deal. Recovery of the Disini commissions has been made even more uncertain after his death in 2014 .

\section{The NBN-ZTE scandal}

The government's deal in 2007 with the Zhongxing Telecommunications Equipment (ZTE) Company, a Chinese state-controlled firm, is another political controversy arising from a 
dubious big-item procurement - the NBN project. It is a complicated case arising from the quarrel for profit and commissions between two competing groups with powerful political sponsors. One group was ZTE, backed by top government officials identified with President Gloria Macapagal-Arroyo (GMA) and her husband, First Gentleman (FG) Mike Arroyo (SBRC, 2009, p. 1). At the time of the scandal, the unpopular GMA administration was already beleaguered by other election-related controversies, such as the Hello Garci scandal and the Fertilizer Fund Scam.

The other group was led by Jose "Joey" de Venecia III, son of House Speaker Jose de Venecia (JDV). De Venecia's group, Amsterdam Holdings, Inc. (AHI) submitted an unsolicited bid for a Build-Operate-Transfer (BOT) scheme, purportedly at no cost to the government. Before the scandal, Speaker JDV was allied to GMA. Associated with the House Speaker was National Economic Development Authority (NEDA) Secretary Romulo Neri (SBRC, 2009, p. 1).

On 21 April 2007, the government through the Department of Transportation and Communication (DOTC) headed by Secretary Leandro Mendoza signed a supply contract with ZTE for the NBN project. A week after, newspaper columnist Jarius Bondoc revealed the involvement of an unnamed official of the Commission on Elections (Comelec) in the allegedly overpriced deal (ABS-CBN News, 2009). That official was later identified as Comelec Chairman Benjamin Abalos, Jr., who lobbied for the ZTE deal. Later, Joey De Venecia led in exposing anomalies in the deal.

On 11 September 2007, acting on a complaint from a House representative, the Supreme Court issued a temporary restraining order for the project. A week later, the Senate Committee on Accountability of Public Officers and Investigations Committee (or the Senate Blue Ribbon Committee [SBRC] began a two-year investigation of possible ethical violations. Later that month, President Arroyo suspended the NBN project and then, on 2 October during her state visit to China, cancelled the ZTE contract (SBRC, 2009, p. 32).

Despite the contract's cancellation, the SBRC decided to continue its investigation. Two years later, it recommended further investigation with the view of filing graft charges against the president and her spouse, House Speaker de Venecia and his son, Comelec chairman Abalos, NEDA Secretary Romulo Neri, some whistle-blowers and other government officials involved (SBRC, 2009, pp. 110-118).

Since the initial exposé broke out in late April 2007, the Arroyo government attempted to minimize the scandal's impact by moving certain officials and personalities involved in the deal (SBRC, 2009, pp. 32, 57). In August, NEDA Secretary Neri was transferred to the Commission on Higher Education. His friend and technical adviser, Rodolfo Lozada, was sent to Hong Kong to avoid testifying before the Senate. In October 2007, amidst the Senate inquiry, Abalos resigned from his post as the Comelec chair.

\section{Allegation of overpricing}

ZTE's NBN deal with the government was negotiated within the framework of the Philippine-China Economic Partnership, which was established in June 2006 as a result of China's diplomatic offensive in Southeast Asia. Based on this agreement, the Philippine government signed an memorandum of understanding with ZTE, allowing the latter to invest in information technology projects in the Philippines, including the NBN project (SBRC, 2009, pp. 15-16). On 7 August, ZTE formally submitted to the Commission on Information and Communications Technology (CICT) its proposal to supply equipment and services for the NBN. The CICT was the agency under the DOTC tasked to review the NBN's proposals. In September 2006, China's Export-Import Bank indicated its intention to fund the project as a loan to the Philippines. The loan component ran contrary to GMA's initial preference for a BOT scheme, as expressed in NEDA's November 2006 Board meeting (SBRC, 2009, p. 22).

The two proposals bore different implications in terms of ownership and control. AHI's BOT scheme meant that the private company would run the enterprise until its agreed date of 
PAP

23,1

transfer to the government. In contrast, the ZTE proposal meant that the broadband network would be owned and operated by the Philippine government while the procurement of equipment, services, and financing would come from China (People of the Philippines vs. Arroyo et al., 2016, p. 15). The DOTC later rejected the AHI's proposal because according to Secretary Mendoza, AHI was insufficiently capitalized to undertake a massive government project (SBRC, 2009, p. 54). As such, the ZTE was the only proposal left for consideration in the NBN project.

The design and cost of the original ZTE proposal submitted to the CICT was not clearly established during the Senate investigation or during the Sandiganbayan trial. Witness testimonies at the Senate revealed different design coverages and costs ranging from US\$262 million to US\$289 million. A revised ZTE proposal, incorporating the DOTC's suggestions of increased coverage and technical requirements, was endorsed by the NEDA at a contract price of US\$379 million. In a NEDA board meeting, GMA ordered the modification of the proposal and removal of overlapping components of the NBN project with the Department of Education's Cyber Education Project (People of the Philippines vs. Arroyo et al., 2016, p. 14). The purported final contract price signed in April 2007 by DOTC and ZTE was US\$329 million.

\section{Unethical acts}

The SBRC report suggested several improprieties committed by government officials and private individuals in the deal. At the centre of the political controversy were Comelec Chair Abalos and FG Arroyo, alleged brokers who received commissions for their services. Both Abalos and Arroyo, as a private individual though married to the president, had no official capacity to intervene in the deal. A Senate witness identified other brokers particularly Ruben Reyes, a private businessman and alleged close friend of GMA's brother (SBRC, 2009, p. 62; Sabangan, 2008).

Testimonial evidence established Abalos' lobbying and bribery attempts. Neri had informed GMA of the Abalos bribe offer to him, to which the president advised non-acceptance (SBRC, 2009, p. 49). De Venecia also claimed a US\$10 million bribe offer from Abalos for withdrawal of the AHI proposal. But de Venecia's insistence to pursue his proposal later led Mike Arroyo to demand that he withdrew from the project (SBRC, 2009, pp. 38-39, 42).

The SBRC report also found it improper for the president to be playing golf and having lunch at ZTE's Shenzhen headquarters in November 2006 since the company was lobbying for a contract. It further pointed out the president's tolerance of corruption, as she knew about Abalos' bribe offer to Neri as well as other irregularities in the broadband contract (SBRC, 2009, pp. 90-91).

The SBRC believed that Speaker JDV and his son likewise committed unethical practices (SBRC, 2009, pp. 113, 115). Speaker JDV tried to distance his involvement from the project by telling the SBRC that his presence in Shenzhen was due to the invitation of the president (SBRC Report, 2009, p. 76). Nevertheless, he showed his hand at influencing government by inviting the DOTC Secretary Mendoza for breakfast at his home. It was there that JDV introduced Mendoza to his son, Joey and informed Mendoza of Joey's DOTC project (SBRC, 2009, p. 48). The SBRC argued that both he and his son attempted to commit graft since by law, relatives of the House Speaker up to the third civil degree, were not supposed to intervene or engage in a business, transaction or contract with the government.

\section{Ombudsman politics and court decision}

Before the SBRC hearings ended in August 2009, the OMB released the results of its own investigation. The OMB cleared GMA and her husband but recommended the filing of 
administrative and criminal charges against Abalos and Neri. Ombudsman Merceditas Gutierrez was Mike Arroyo's schoolmate in one of the country's prestigious universities. Prior to her appointment as Ombudsman, she was GMA's former justice secretary.

After Benigno Aquino III assumed the presidency in 2010, the winds of Philippine politics shifted. The persecution of GMA and other government officials began. The House of Representatives impeached Ombudsman Gutierrez and she resigned in April 2011 before the conviction trial at the Senate. She was succeeded by former Supreme Court associate justice Conchita Carpio-Morales. It should be noted that, contrary to tradition, it was the retiring Carpio-Morales who swore in Aquino as president and not then Supreme Court Chief Justice Renato Corona. Corona, whom Aquino resented for accepting GMA's midnight appointment as chief justice, was later impeached (Batalla et al., 2018b, p. 133).

In December 2011, on the basis of a formal complaint by representatives of certain leftwing groups, the Ombudsman filed charges against the Arroyo spouses, Comelec Chair Abalos and former DOTC Secretary Mendoza for conspiring to commit illegal acts that culminated in the signing of the NBN-ZTE contract. The charge against GMA et al. was for violation of Section 3(g) of the Anti-Graft and Corrupt Practices Act. Specifically, the provision of the law prohibited public officials from "entering, on behalf of the Government, into any contract or transaction manifestly and grossly disadvantageous to the same, whether or not the public officer profited or will profit thereby" (Republic Act No. 3019, 1960). The Ombudsman argued that the contract was "grossly and manifestly disadvantageous" to the government because (1) the actual cost of the ZTE proposal was US $\$ 130$ million and therefore overpriced at the signed contract price of US\$329 million; (2) the ZTE project covered only $30 \%$ of the country compared to the AHI's proposal of $80 \%$ coverage and (3) the project was to be financed by a loan from China versus the AHI's BOT proposal which would not entail any cost to government (People of the Philippines vs. Arroyo et al., 2016, p. 2). In hindsight, the claims advanced by the Ombudsman in its case reflected the bias favouring the previous Senate testimonies of de Venecia and others in the opposition.

In late 2011, GMA and Abalos were charged and jailed for electoral fraud. Then in March 2012 , on the basis of the Ombudsman's charges related to the NBN-ZTE project, the Sandiganbayan issued warrants of arrest for Mike Arroyo and Mendoza. Both men were freed after posting bail on the day of their arrest.

On 1 March 2016, the government prosecution finished presenting its case before the Sandiganbayan. Soon after, the accused asked the court to allow them to file a demurrer to evidence. A demurrer to evidence is a motion to dismiss the case for insufficiency of evidence. On 24 June 2016, the Sandiganbayan granted the request and as provided by the rules of criminal procedure, gave Arroyo et al. 10 days to file demurrers to evidence. Consequently, the accused individuals separately filed their motions for dismissal.

On 25 August 2016, the Sandiganbayan issued its resolution exonerating the Arroyo spouses, Abalos and Mendoza for lack of evidence to establish allegations of overpricing, the existence of a conspiracy and the disadvantages of the ZTE-NBN contract (MacapagalArroyo vs. People of the Philippines and Sandiganbayan, 2016). Apparently, the OMB erred in its reliance on the evidence provided by the opposition during GMA's term.

\section{Comparing the two scandals}

The weaknesses of Philippine governance institutions to curb grand corruption in government procurement projects during the past half-century could be gathered from a comparison of the two scandals. Both scandals share a number of elements from the process of contracting to their resolution.

First, an opportunity for corruption existed based on executive agreements that did not undergo competitive public bidding. Although transpiring under different political regimes, 
PAP

23,1

82

one autocratic and the other democratic, the BNPP and ZTE projects were both based on toplevel agreements with foreign entities that made contracting less transparent to the public.

Second, that executive agreements could be made without competitive public bidding encouraged the formation of corrupt rent-seeking relationships at the top levels of government. The two megaprojects revealed the importance of brokers and political sponsors-promoters in such relationships. Particularly, they were crucial to easing out the competition and successfully closing deals between the rent-seeking firm and the government.

Third, the lack of transparency in government contracting made the projects susceptible to public allegations of improprieties, which served to bolster the political opposition. Foreign media exposed the anomalous BNPP contract, which drummed up local opposition not only for the corruption but also for the nuclear plant's potential harm to public safety and the environment. In the ZTE case, the media exposé alerted the public of allegations of overpricing due to huge commissions. Negative public opinion to the project of an already politically beleaguered Arroyo presidency prompted an inquiry from the Senate leading to the project's cancellation.

The fourth element relates to the erratic behaviour and questionable competence of prosecutorial agencies dealing with grand corruption, particularly the OMB and PCGG. The PCGG was able to gather voluminous evidence against the Marcoses and their cronies. However, important pieces of evidence were not properly handled as attested by the testimonies of PCGG personnel in Republic of the Philippines versus Disini et al. (2012). The court found no convincing proof of Marcos' ownership of the Herdis companies or his financial gain from the Westinghouse deal.

Similarly, the two cases raise questions concerning the OMB's competence and behaviour. In 1997, Ombudsman Desierto dropped the graft charges against Disini for lack of prima facie evidence, despite the PCGG evidence. On appeal by the latter, the Supreme Court in 2003 ruled that the Ombudsman exercised grave abuse of discretion. Thus, it reversed Desierto's decision and directed the OMB to file the appropriate criminal charges against Disini (PCGG vs Desierto et al., 2003). Consequently, the new Ombudsman at the time of the Supreme Court decision filed graft charges against the Marcos crony. In 2012, the Sandiganbayan ruled in favour of the government.

In 2009, Ombudsman Gutierrez dropped charges against GMA in connection with the NBNZTE project because of her immunity from being sued as the president. She also cleared GMA's husband. In 2012, when the prevailing political fervour was against the former president, her successor Ombudsman Carpio-Morales, hastily filed charges against the Arroyos, Abalos and Mendoza. Insufficient evidence to graft charges led to the Sandiganbayan's exoneration of the accused in August 2016. In an earlier court decision, the Supreme Court also acquitted Arroyo for lack of evidence in a plunder case involving the alleged misuse of intelligence funds of the Philippine Charity Sweepstakes Office (Macapagal-Arroyo vs People of the Philippines, 2016). The petition was filed in July 2012 by Carpio-Morales.

A politically subservient or accommodating judiciary might be argued to be the fifth element in the legal settlement of both corruption scandals. The Sandiganbayan and the Supreme Court decided on the Disini case during President Benigno Aquino's term. Aquino was of course against Marcos and his cronies. It was also during his term that criminal charges were filed against GMA. The Sandiganbayan's ruling on the ZTE case, issued in the early days of the Duterte presidency, favoured the Arroyos and other co-accused. In her 9 July 2019 farewell dinner speech as Congress representative and House Speaker, GMA thanked Duterte, whose presidency "provided the atmosphere in which the Court had the freedom to acquit" her of the "trumped-up charges" of his predecessor (Panganiban, 2019). Her remark was suggestive of the political malleability of the courts.

Sixth, both projects contained the element of foreign government participation, therefore entailing diplomatic considerations. In this regard, the government had to take utmost care of 
relevant, confidential information in order to prevent scandals from erupting and harming diplomatic relations. It was therefore possible that discovered irregularities made it difficult for the governments involved to publicly acknowledge or outrightly denounce the projects. In the BNPP project, the U.S. government was involved directly through the project loan financing provided by the U.S. Export-Import Bank. It was also involved indirectly through the support of its nuclear export industry and support of private banks. In the NBN project, direct Chinese government participation came through the ZTE, a state-controlled firm, and the China Export-Import Bank for loan financing.

Finally, after the initial media exposés, the Marcos and Arroyo governments failed to effectively contain the scandals from further prolongation or escalation. To dismiss the Disini connection in the Westinghouse deal, Marcos explained that the decision was based on an earlier report of foreign consultants. Further, in reaction to the U.S. media pressure, Marcos immediately ordered the investigation of the Westinghouse deal and the government takeover of Disini companies, which were symbolic gestures to affirm his integrity. To be sure, authoritarian rule prevented the discovery of other incriminating evidence on the legal improprieties of the BNPP contract. However, no amount of damage control could erase the image of the BNPP project as a symbol of Marcos' corruption.

The Arroyo government's damage control included the cancellation of the NBN-ZTE contract as well as the suppression of key witnesses (e.g. Neri) from disclosing sensitive information to the public. However, such measures only fuelled further public suspicions and strengthened the justification for the SBRC's prolonged investigation of the scandal.

What obviously contrasts the two projects is that the ZTE contract never pushed through unlike the BNPP, whose liabilities had to be settled for decades. The ZTE project cancellation was the product of the system of checks and balances in post-Marcos democracy, with pressure exerted by the mass media, Congress, the courts and public opinion. However, this system of checks and balances has not guaranteed the absence of grand corruption in the country.

Despite the Government Procurement Reform Act of 2003, which mandates that all government projects to undergo competitive public bidding, the apparent loophole revealed by the ZTE-NBN experience was the government-to-government agreement, which provided an exception to the general rule. This point raised contrasting legal opinions yet to be resolved (Suplico vs NEDA, 2008). That rules could be changed and broadly interpreted to favour particularistic interests does not bode well for the promotion of a culture of accountability and integrity in government in the Philippines.

\section{Conclusion}

The BNPP and NBN-ZTE scandals illustrate cases of corrupt relationships formed at the highest levels of government in contracting large infrastructure projects in the Philippines. Such projects, extending to national roadworks and other major undertakings, are often susceptible to political interference for the private gain of public officials (Batalla et al., 2018a).

The constancy of grand corruption scandals in the Philippines suggests deeper problems in politics and society. First, many government institutions remain malleable to negative external influences. This is because the bureaucracy, lacking in both capacity and autonomy, has long been "subordinated to particularistic elite interests" (Hutchcroft, 1998, p. 26). Despite governance reforms through decades of restored democracy, many government institutions are still easily influenced by powerful vested interests.

Second, strong incentives to commit graft persist. Such incentives are not only exclusive to politicians, political appointees and professional bureaucrats but also to foreign governments, private firms and individual brokers. The persistence of corruption incentives in many government institutions draws from underdeveloped governance 
PAP

23,1

measures, the prevailing culture of corruption, low civil service wages and the low risk of detection with a promise of high returns (Quah, 2013, pp. 127-132).

Finally, there is the perceived failure of closure to past scandals by the justice system, as there continues to be a "low risk" of punishment (Quah, 2013, p. 129). With the exception of the conviction of President Estrada for plunder (though later pardoned by Arroyo), no other highranking official above the position of provincial governor has ever been convicted of corruption (Bolongaita, 2010). At best, high-ranking officials accused of corruption have been shamed and jailed. Some senators including Juan Ponce Enrile, Ramon Revilla Jr. and Jose Ejercito Jr. were jailed in connection with the Napoles pork barrel scam but have been either released on bail or acquitted of plunder charges. The failure of closure of past scandals encourages corrupt practices by top officials, who regard government as a lucrative source of private wealth and power. The scandals provide a constant reminder of the long unattended opportunity of effectively reforming the political system.

\section{References}

ABS-CBN News (2009), "After 22 years, govt ends presentation of case vs Marcos, Disini”, 16 February, available at: https://news.abs-cbn.com/nation/02/15/09/after-22-years-govt-endspresentation-case-vs-marcos-disini (accessed 3 September 2019).

ABS-CBN News (2014), "BNPP broker Herminio Disini passes away," 16 June, available at: https:// news.abs-cbn.com/business/06/16/14/bnpp-broker-herminio-disini-passes-away (accessed 20 August 2019).

Asian Wall Street Journal (1995), "Westinghouse, Philippines sign settlement on plant”, 16 October, p. 2.

Batalla, E.V.C., Torneo, A. and Magno, F. (2018a), "A survey of political interference patterns and modalities in national roadworks in the Philippines", Asia Pacific Social Science Review, Vol. 18 No. 3, pp. 57-71.

Batalla, E.V.C., Romana, M.S. and Rodrigo, K. (2018b), "The judiciary under threat,", in Thompson, M.R. and Batalla, E.V.C. (Eds), Routledge Handbook on the Contemporary Philippines, Chapter 10, Routledge, London, pp. 130-143.

Beaver, W. (1994), "Nuclear nightmares in the Philippines", Journal of Business Ethics, Vol. 13 No. 4, pp. 271-279.

Bolongaita, E. (2010), An Exception to the Rule? Why Indonesia's Anti-corruption Commission Succeeds where Others Don't - a Comparison with the Philippines' Ombudsman, U4 Issue, August, No. 4, Chr Michelsen Institute, Bergen.

Branigin, W. (1984), “Crony capitalism' blamed for economic crisis”, Washington Post, 16 August, available at: https://www.washingtonpost.com/archive/politics/1984/08/16/crony-capitalism -blamed-for-economic-crisis/d99e8760-087d-4d25-ad66-3d324150dc4d/ (accessed 22 July 2019).

Bureau of the Treasury (2020), National Government Debt Service, Historical Series, Manila, available at: https://www.treasury.gov.ph/?page_id=4221 (accessed 6 January 2020).

Butterfield, F. (1978), "Marcos, facing criticism, may end \$1 Billion Westinghouse contract", New York Times, 14 January, available at: https://www.nytimes.com/1978/01/14/archives/marcos-facingcriticism-may-end-1-billion-westinghouse-contract.html (accessed 21 August 2019).

Butterfield, F. (1988), "Westinghouse, Jersey firm sued by the Philippines", New York Times, 2 December, available at: https://www.nytimes.com/1988/12/02/business/westinghouse-jerseyfirm-are-sued-by-the-philippines.html (accessed 3 September 2019).

Chang, E. and Golden, M. (2010), "Sources of corruption in authoritarian regimes", Social Science Quarterly, Vol. 91 No. 1, pp. 1-20.

Coronel, S. and Tordesillas, E. (1998), "Grandmother of all scams", Part 3, Philippine Center for Investigative Journalism, 20 March, available at: https:/old.pcij.org/stories/the- grandmother-ofall-scams-3/ (accessed 11 November 2019). 
David-Barrett, E. and Fazekas, M. (2019), "Grand corruption and government change: an analysis of partisan favouritism in public procurement”, European Journal of Criminal Policy and Research, 16 June, doi: 10.1007/s10610-019-09416-4 (accessed 6 January 2020).

Dumaine, B. (1986), “The $\$ 2.2$ billion nuclear fiasco", Fortune, 1 September, available at: https:// archive.fortune.com/magazines/fortune/fortune_archive/1986/09/01/67989/index. htm (accessed19 August 2019).

Hutchcroft, P. (1998), Booty Capitalism: The Politics of Banking in the Philippines, Cornell University Press, Ithaca, NY.

Hutchcroft, P. (2008), "The Arroyo imbroglio in the Philippines", Journal of Democracy, Vol. 19 No. 1, pp. 141-155.

Kukutschka, R.M.B. (2018), “Anti-corruption strategies for authoritarian states”, U4 Helpdesk Answer, 2018:7, 20 May, pp. 1-18, available at: https://www.u4.no/publications/anti-corruption-strategiesfor-authoritarianstates.pdf (accessed 7 January 2020).

Lowi, T. (1988), "Foreword", in Markovits, A.S. and Silverstein, M. (Eds), The Politics of Scandal: Power and Process in Liberal Democracies, Holmes and Meier, New York, NY, pp. vii-xii.

Macapagal-Arroyo, G.M. vs People of the Philippines (2016), "Supreme court, G.R. no. 220598”, 19 July.

Manapat, R. (1991), Some Are Smarter than Others: The History of Marcos' Crony Capitalism, Aletheia Publications, New York, NY.

Mathews, J. and Wideman, B. (1977), "Martial law benefits Marcos' friends”, Washington Post, 19 December, available at: https:/www.washingtonpost.com/archive/politics/1977/12/19/martiallaw-benefits-marcos-friends/38bfac37-6c3d-4b5c-9e50-6864629680ef/ (accessed 21 August 2019).

Mathews, J. and Wideman, B. (1978), "Marcos orders seizure of wealthy friends' companies", Washington Post, 18 January, available at: https:/www.washingtonpost.com/archive/politics/ 1978/01/18/marcos-orders-seizure-of-wealthy-friends-companies/5cec6171-4a3f-bba3-bef235c90eb2/ (accessed 21 August 2019).

Mydans, S. (1988), "In post-Marcos Philippines, corruption still a way of life", New York Times, 17 October, available at: https://www.nytimes.com/1988/10/17/world/in-post-marcos-philippines -corruption-still-a-way-of-life.html (accessed 11 November 2019).

Panganiban, A.V. (2019), "Judicial subservience and independence", Philippine Daily Inquirer, 15 September, p. A13.

People of the Philippines vs. Gloria Macapagal-Arroyo, Jose Miguel Arroyo, Benjamin Abalos, Sr. and Leandro Mendoza (2016), "SB-11 CRM-0467”, 25 August.

Presidential Commission on Good Government (PCGG) vs. Desierto, Ananiano, Herminio T. Disini, Paciencia Escolin-Disini, Angel E. Disini, Liliana L. Disini, and Lea Disini (2003), "Supreme Court G.R. No. 132120", 10 February.

Quah, J.S.T. (2013), Curbing Corruption in Asian Countries: An Impossible Dream?, ISEAS Publishing, Singapore.

Republic Act No. 3019 (1960), "Anti-graft and corrupt practices act”, Official Gazette, available at: https://www.officialgazette.gov.ph/1960/08/17/republic-act-no-3019/ (accessed 4 September 2019).

Republic of the Philippines (1980), Letter of Instructions No. 1065, Manila, 15 September, available at: https://www.officialgazette.gov.ph/downloads/1980/09sep/19800915-LOI-1065-FM.pdf (accessed 15 September 2019).

Republic of the Philippines vs. Disini, Herminio et al. (2012), "Sandiganbayan, Civil Case No. 0013", 11 April.

Republic of the Philippines vs. Westinghouse Electric (1989), "U.S. District Court for the District of New Jersey, 714 F. Supp. 1362 (D.N.J. 1989)”, 18 May, available at: https://law.justia.com/cases/ federal/district-courts/FSupp/714/1362/2258760/ (accessed 21 September 2019).

Rimando, L. (2000), "Estrada, Villar and stock market—something in common?", ABS-CBN News, 24 April, available at: https://news.abs-cbn.com/nation/04/24/10/estrada-villar-and-stock-market\% E2\%80\%94something-common (accessed 11 November 2019). 
PAP

23,1

86

Sabangan, A.R. (2008), "NBN-ZTE's gang of four", GMA News Online, 13 March, available at: https:// www.gmanetwork.com/news/news/content/84644/nbn-zte-s-gang-of-four/story/ (accessed 4 September 2019).

Salaverria, L. (2012), "Sandiganbayan orders Marcos crony to return $\$ 50-\mathrm{M}$ loot in nuclear plant deal”, Philippine Daily Inquirer, 13 April, available at: https:/newsinfo.inquirer.net/175813/ sandiganbayan-orders-marcos-crony-to-return-50-m-loot-in-nuclear-plant-deal\#ixzz5uMzLke00 (accessed 20 August 2019).

Senate Blue Ribbon Committee (SBRC) (2009), "NBN-ZTE, committee report no. 743”, Senate of the Philippines, 11 November, available at: https://www.senate.gov.ph/lisdata/1293411633!.pdf (accessed 4 September 2019).

Suplico, R. vs. National Economic Development Authority, Department of Transportation and Communications, and ZTE Corporation, Amsterdam Holdings, and All Persons Acting in their Behalf (2008), "Supreme Court G.R. No. 178830”, 14 July.

Tiglao, R. (1992), "Reasons of state: Citicorp report ignored by Philippine government", Far Eastern Economic Review, Vol. 155 No. 10, 12 March, p. 47.

Transparency International (2016), "What is grand corruption and how can we stop it", 21 September, available at: https://www.transparency.org/news/feature/what_is_grand_corruption_and_ how_can_we_stop_it (accessed 6 January 2020).

United Nations Office on Drugs and Crime (UNODC) (2019), "Corruption and democracy", AntiCorruption Module 3: Corruption and Comparative Politics, December, available at: https:// www.unodc.org/e4j/en/anti-corruption/module-3/keyissues/corruption-and-democracy.html (accessed 7 January 2020).

United Press International (1991), "Westinghouse cleared of bribing Marcos", 20 December, available at: https:/www.upi.com/Archives/1991/12/20/Westinghouse-cleared-of-bribing-Marcos/2805693205200/ (accessed 21 September 2019).

United States Nuclear Regulatory Commission (USNRC) (2018), "Three mile Island accident", Backgrounder, Office of Public Affairs, June, available at: https:/www.nrc.gov/docs/ML0402/ ML040280573.pdf (accessed 24 August 2019).

Velasco, G. (2006), Trailblazing: The Quest for Energy Self-Reliance, Anvil, Manila.

\section{Further reading}

Batalla, E.V.C. (2015), "Treading the straight and righteous path: curbing corruption in the Philippines", Asian Education and Development Studies, Vol. 4 No. 1, pp. 51-75.

Butterfield, F. (1986), "Filipinos say Marcos was given millions for '76 nuclear contract", New York Times, 17 March, available at: https:/www.nytimes.com/1986/03/07/world/filipinos-say-marcoswas-given-millions-for-76-nuclear-contract.html (accessed 3 September 2019).

\section{About the author}

Eric V.C. Batalla is Professor at the Political Science Department, De La Salle University, Manila, Philippines. He is co-editor of the Routledge Handbook of the Contemporary Philippines (2018) and the author of several journal articles and book chapters on regional and Philippine politics, corruption and economic development. Eric V.C. Batalla can be contacted at: eric.batalla@dlsu.edu.ph

For instructions on how to order reprints of this article, please visit our website:

www.emeraldgrouppublishing.com/licensing/reprints.htm

Or contact us for further details: permissions@emeraldinsight.com 